\title{
The relationship between types of physical disabilities and the Instrumental Activities of Daily Living (IADL) in the elderly
}

\author{
YELIZ MERCAN ${ }^{1, A-F}$, KEVSER TARI SELCUK ${ }^{2, A-F}$, AYLIN AYDIN SAYILAN ${ }^{1, A, ~ B, ~ E, ~ F ~}$ \\ ORCID ID: 0000-0002-7099-4536 ORCID ID: 0000-0003-05768732 \\ ${ }^{1}$ Kirklareli University School of Health, Kirklareli, Turkey \\ ${ }^{2}$ Bandirma Onyedi Eylul University Faculty of Health Sciences, Balikesir, Turkey
}

A - Study Design, B - Data Collection, C - Statistical Analysis, D - Data Interpretation, E - Manuscript Preparation, F - Literature Search, G - Funds Collection

Summary Background. The increase in the elderly population and life expectancy may lead to increased dependence and disability in performing Instrumental Activities of Daily Living (IADL).

Objectives. We aimed to determine the relationship between types of physical disabilities and the Instrumental Activities of Daily Living (IADL) score in people 65 years of age and over.

Material and methods. This study was designed as a multicenter, cross-sectional survey that was conducted in Kirklareli, Turkey. The study involved 578 people who were 65 years of age or over and presented to a Family Health Center for any reason. The Lawton and Brody IADL Scale was used to assess activities of daily living (ADL) levels in these elderly participants.

Results. We found that $32.9 \%$ of all participants and $46.1 \%$ of participants with a physical disability experienced a limitation in at least one ADL. After adjusting for descriptive characteristics, people with hearing impairments ( $A O R=5.32,95 \% \mathrm{Cl}: 2.41-11.72, p<0.001$ ) and orthopedic disorders ( $A O R=3.65,95 \% \mathrm{Cl}: 1.80-7.38, p<0.001$ ) were likely to be dependent on other people while performing ADLs. The likelihood of ADL dependency was lower in participants with visual impairments than it was in those without any visual impairment (AOR= 0.21, 95\% Cl: 0.09-0.49, $p<0.001$ ).

Conclusions. ADL limitations are more likely to occur in elderly people with disabilities. The likelihood of ADL dependency was higher in people with a hearing impairment or an orthopedic disorder. This finding should be taken into consideration in studies that aim to improve the health of the elderly.

Key words: activities of daily living, disabled persons, aged.

Mercan Y, Tari Selcuk K, Aydin Sayilan A. The relationship between types of physical disabilities and the Instrumental Activities of Daily Living (IADL) in the elderly. Fam Med Prim Care Rev 2021; 23(1): 22-28, doi: https://doi.org/10.5114/fmpcr.2021.103153.

\section{Background}

The changes that constitute and influence aging are complex. The World Health Organization defines healthy aging as the process of developing and maintaining the functional ability that enables well-being at an older age [1]. Activities of daily living (ADLS) and instrumental ADLs (IADLs) are fundamental to the maintenance of independence in the elderly [2]. Older people who experience a decrease in their physiological reserve may be frail or need help meeting their basic needs [1, 3].

The ability to perform ADLs is dependent upon cognitive, motor and perceptual abilities, and ADL performance is sensitive to early cognitive decline [4]. In recent years, ADL limitation rates have been reported to range from $11-84 \%$ [4-7]. Several previous studies have shown that older women have a higher risk of ADL dependency than do men, that a more advanced age carries a higher risk of dependency and that comorbidity causes a decrease in ADL performance [7-9]. A low education level, poor income level and poor social support systems have also been reported to adversely affect the performance of ADLs $[5,10,11]$.

Limitations in performing self-care and in the ability to engage in activities essential to independent community living are indicators of disability [1]. It has been reported that disability increases as functional capacities decrease in old age and that the elderly experience greater ADL limitations [3, 12]. Evidence shows that the loss of senses, such as hearing and vision [13,14], changes in muscle structure or bone density [15] or common chronic conditions that develop following dementia or stroke due to aging lead to a decrease in ADL capabilities [11, 16, 17]. Mueller-Schotte et al. reported that the risk of ADL limitations was twice as high in people with dual sensory loss or hearing loss, which severely reduced the elderly's performance of household tasks, traveling, shopping, preparing meals and walking [18]. A study conducted in China reported that $49.17 \%$ of those 80 years of age or older with multiple comorbidities had ADL limitations; as the number of chronic conditions increased, so did the risk of ADL limitations, which ranged from 1.53-5.61 [7].

The worldwide increase in the elderly population and in human life expectancy in general may lead to increased dependence and disability while performing ADLs [1]. ADL dependency results in poor quality of life and a decline in the number of healthy years of life, as well as the overall life expectancy; dependency also increases both the burden of a disease and the care costs for the elderly, which impact not only the elderly but also their family and caregivers and raise the social burden [1, 19]. Therefore, it is a priority to assess the current situation and identify existing deficits in the elderly and in elderly people with a disability to make accurate projections about their health and needs in the future and also to develop evidence-based prevention strategies. 


\section{Objectives}

In 2017, 8.5\% of the population in Turkey was at least 65 years of age, while $11.7 \%$ of residents in the city center of Kirklareli were in this same age group [20]. Our search for studies conducted to investigate IADL in the elderly aged 65 and over living in Kirklareli, a city located in northeast Turkey and southwest Europe, revealed a gap in literature. There is no study evaluating IADL levels according to the type of disability that has been conducted in the elderly with disabilities. Given the possibility of the increase in the elderly population in the coming years, this study is expected to provide a reference for efforts to plan essential health services and social support systems for the elderly population in this city. Therefore, the aim of this study was to investigate the relationship between the types of physical disabilities and instrumental ADLs in the elderly.

\section{Material and methods}

\section{Study design}

The present study was conducted between August 2018 and October 2018 in eight Family Health Centers (FHCs) in Kirklareli, a province in northwestern Turkey. The number of people 65 years of age and over in the Kirklareli city center in 2017 was 11,759 [20]. The minimum sample size that was required in the study was calculated as 372 by assuming $n=11759, p=0.50$, $\alpha=0.05$ and $d=0.05$ using the Epi Info 7.2 software program. However, we decided to include $50 \%$ more people due to the possibility of refusals, withdrawals and/or losses during the study. Therefore, the goal was to reach a sample size of at least 558 people. The number of elderly people who presented to each of the eight FHCs in the Kirklareli Central District in one day ranged from five to seven. Between 13 August 2018 and 28 October 2018, 578 elderly people presented to the FHCs, and they were interviewed only once at their first presentation. The inclusion criteria of the study were being in the 65 and over age group, consulting with the FHC for any reason, having the cognitive and mental ability to answer questions and volunteering to participate in the study. The exclusion criteria of the study were difficulty in performing ADLs for less than three months and failing to complete the questionnaire.

\section{Data collection}

The study data was collected using the Personal Information Form prepared by the researchers, and the IADL Index was completed using face-to-face interviews. The interviews were performed in a room allocated for the interviews at the FHCS and lasted for approximately 15-20 minutes.

IADL Index: The IADL Index was developed by Lawton and Brody in 1969. A study of the validity and reliability of the Turkish version of the IADL was carried out by Onal Yardimci in 1995 [21]. The IADL Index is used to assess a person's level of independent living skills. The IADL includes eight items that question the following: using the phone, shopping, preparing meals, doing household tasks, laundering, traveling, managing medications and handling money. While an IADL Index score from 0-8 indicates dependence, scores from 9-16 and 17-24 suggest semi-dependence and independence, respectively. In the present study, elderly participants whose IADL Index score was 17 or greater were considered dependent. The Cronbach's Alpha value of the IADL scale was 0.85 in a study conducted in people over the age of 65 years [22] and was 0.87 in the present study, which are similar values.

\section{Variables of the study}

\section{Dependent variables}

The dependent variable of the study was limitations in ADLs. These limitations, for at least three months, included having difficulty using the phone, shopping, preparing meals, doing household tasks, laundering, traveling, managing medications and handling money.

\section{Independent variables}

The independent variables of the study were the different types of physical disabilities. The questions that explored the types of physical disabilities and assessed for the presence of a chronic disease were written using an open-ended format. The responses were based on the participants' declaration. In this study, hearing impairments, vision impairments, speech impairments, orthopedic dysfunctions or structural disorders reported by the participants were evaluated according to the relevant diagnostic code in the International Classification of Functioning, Disability and Health (ICF) and then classified accordingly. The presence of at least one hearing, visual, speech or orthopedic disorder was considered as a physical disability. Chronic diseases refer to conditions that last for at least one or more years and require ongoing medical attention or limit ADLs or both [23]. The respondent's highest education level was divided into the following options: illiterate, literate (not a graduate of any school but able to read and write), primary school, secondary school or higher. In our analysis, these options were simplified into the categories of either "literate and illiterate" or "primary school or higher".

\section{Ethical consideration}

The present study was conducted in accordance with ethical principles and was approved by the Ethics Committee of the Kirklareli University Institute of Health Sciences in 2018 (Reference number: March 09, 2018/P081R00). Official permission to conduct the study was received from the Republic of Turkey Ministry of Health (Reference number: July 20, 2018/49654233604.02-E.1094). The participants were first informed about the purpose and scope of the study, and their written and verbal informed consent was then obtained.

\section{Data analysis}

Descriptive statistics were used to analyze the study data, and a Pearson's chi-squared test was carried out to compare the rates in the independent groups. A multivariate binary logistic regression analysis (Enter strategy) was used to investigate the relationship between the type of physical disability and the extent of IADL dependency. Dummy variables were created for variables with three or more categories included in the model. Of these variables, being in the 65-74 age group, having an education level of primary school or above, having a higher number of people living together (at least one) and reporting a perceived health level of at least moderate or good were used as the reference group $(0)$ and were compared with all the other categories (1). In the univariate analysis, variables with a $p$-value $<0.05$ were considered significant in literature [24] and were therefore included in the model. The models were adjusted for age, gender, education level, number of people the participants lived with, perceived income level, perceived health level and chronic diseases $[5,6,10,11]$. The explanatory value of the models was evaluated using the Nagelkerke R. Square (Nagelkerke $R^{2}$ ). $p$-values $<0.05$ were considered statistically significant. Analysis was performed using the Statistical Package for the Social Sciences, version 22.0 (SPSS Inc., Chicago, IL, USA).

\section{Results}

The descriptive characteristics of the participants are shown in Table 1. The mean age of the participants was $73.78 \pm 6.20$ years (range: $65-89$ ). Of them, $53.5 \%$ were female, and $30.8 \%$ reported having at least one physical disability. The mean score 
the participating elderly obtained on the IADL was $18.32 \pm 4.42$ (range: $8-24$ ), and $32.9 \%$ of all participants experienced a limitation in at least one IADL (Table 1).

\begin{tabular}{|c|c|c|}
\hline Variables & $n$ & $\%$ \\
\hline $\begin{array}{l}\text { Gender } \\
\text { female } \\
\text { male }\end{array}$ & $\begin{array}{l}309 \\
269\end{array}$ & $\begin{array}{l}53.5 \\
46.5\end{array}$ \\
\hline $\begin{array}{l}\text { Age mean } \pm \text { SD: } 73.78 \pm 6.20 \text { (Min: 65, Max: } 89) \\
65-74 \\
75-84 \\
85+\end{array}$ & $\begin{array}{l}323 \\
213 \\
42\end{array}$ & $\begin{array}{l}55.9 \\
36.9 \\
7.3\end{array}$ \\
\hline $\begin{array}{l}\text { Education level } \\
\text { secondary school or higher } \\
\text { primary school } \\
\text { literate } \\
\text { illiterate }\end{array}$ & $\begin{array}{l}75 \\
275 \\
127 \\
101\end{array}$ & $\begin{array}{l}13.0 \\
47.6 \\
22.0 \\
17.5\end{array}$ \\
\hline $\begin{array}{l}\text { Number of people the participants live together } \\
\text { with } \\
\text { alone } \\
\text { one } \\
\text { two or more }\end{array}$ & $\begin{array}{l}95 \\
203 \\
262 \\
\end{array}$ & $\begin{array}{l}17.0 \\
36.3 \\
46.8 \\
\end{array}$ \\
\hline $\begin{array}{l}\text { Perceived income level } \\
\text { adequate } \\
\text { inadequate }\end{array}$ & $\begin{array}{l}468 \\
110 \\
\end{array}$ & $\begin{array}{l}81.0 \\
19.0\end{array}$ \\
\hline $\begin{array}{l}\text { Perceived health level } \\
\text { good } \\
\text { moderate } \\
\text { poor }\end{array}$ & $\begin{array}{l}136 \\
274 \\
168\end{array}$ & $\begin{array}{l}23.5 \\
47.4 \\
29.1\end{array}$ \\
\hline $\begin{array}{l}\text { Chronic disease } \\
\text { no } \\
\text { yes }\end{array}$ & $\begin{array}{l}90 \\
488\end{array}$ & $\begin{array}{l}15.6 \\
84.4\end{array}$ \\
\hline $\begin{array}{l}\text { Physical disability } \\
\text { no } \\
\text { yes }\end{array}$ & $\begin{array}{l}400 \\
178 \\
\end{array}$ & $\begin{array}{l}69.2 \\
30.8\end{array}$ \\
\hline Physical disability type & & \\
\hline $\begin{array}{l}\text { Hearing impairment } \\
\text { no } \\
\text { yes }\end{array}$ & $\begin{array}{l}534 \\
44\end{array}$ & $\begin{array}{l}92.4 \\
7.6\end{array}$ \\
\hline
\end{tabular}

\begin{tabular}{|l|l|l|}
\hline $\begin{array}{l}\text { Vision impairment } \\
\text { no } \\
\text { yes }\end{array}$ & 491 & 84.9 \\
\hline $\begin{array}{l}\text { Speech impairment } \\
\text { no } \\
\text { yes }\end{array}$ & 57 & 15.1 \\
\hline $\begin{array}{l}\text { Orthopedic disorders } \\
\text { no }\end{array}$ & 8 & 98.6 \\
yes & 508 & 87.9 \\
\hline $\begin{array}{l}\text { IADL levels mean } \pm \text { SD: } 18.32 \pm 4.42 \text { (Median: } \\
\text { 18.00, Min: 8, Max: 24) }\end{array}$ & 70 & 12.1 \\
$\begin{array}{l}\text { independence mean } \pm \text { SD: } 20.83 \pm 2.56 \text { (Me- } \\
\text { dian: 20.00, Min: 17, Max: } 24)\end{array}$ & & \\
dependence mean \pm SD: $13.20 \pm 2.66$ (Median: & 388 & 67.1 \\
13.00, Min: 8, Max: 16) & 190 & 32.9 \\
\hline
\end{tabular}

According to IADL type, $28.9 \%$ of all participants were dependent on others for traveling, $23.9 \%$ for shopping and $21.5 \%$ for doing household chores, whereas $37.6 \%$ of the participants with a physical disability were dependent on others for shopping, $33.1 \%$ for using the phone and $32.0 \%$ for traveling. Given the types of disabilities reported by the elderly participants, those with hearing and speech impairments experienced limitations in using the phone ( $68.2 \%$ and $25 \%$, respectively), those with orthopedic disorders reported limitations in shopping (71.4\%), and those with vision impairments experienced limitation in laundering $(21.8 \%)$ (Table 2 ).

Table 3 shows a comparison of the IADL dependency status of the elderly according to some descriptive characteristics and the type of physical disability. In the study, factors such as gender $(p=0.040)$, age $(p=0.011)$, number of people the participants lived with $(p<0.001)$, perceived health level $(p<$ $0.001)$, presence of a chronic illness $(p<0.001)$ and presence of a physical disability $(p<0.001)$ were determined to significantly affect IADL scores. Overall, $46.1 \%$ of participants with a physical disability experienced a limitation in at least one IADL. Participants with hearing impairments $(50 \%, p=0.012)$ and those with orthopedic disorders $(77.1 \%, p<0.001)$ were more dependent on others for performing IADLs, while those with visual impairments $(17.2 \%, p<0.001)$ were able to perform these activities more independently (Table 3 ).

\begin{tabular}{|c|c|c|c|c|c|c|c|c|}
\hline & \multicolumn{2}{|c|}{ Using the phone } & \multicolumn{2}{|l|}{ Shopping } & \multicolumn{2}{|c|}{ Preparing meals } & \multicolumn{2}{|c|}{ Household task } \\
\hline & $\begin{array}{l}\text { Indepen- } \\
\text { dence }\end{array}$ & $\begin{array}{l}\text { Depen- } \\
\text { dence }\end{array}$ & \begin{tabular}{|l|}
$\begin{array}{l}\text { Indepen- } \\
\text { dence }\end{array}$ \\
\end{tabular} & $\begin{array}{l}\text { Depen- } \\
\text { dence }\end{array}$ & $\begin{array}{l}\begin{array}{l}\text { Indepen- } \\
\text { dence }\end{array} \\
\end{array}$ & \begin{tabular}{|l}
$\begin{array}{l}\text { Depen- } \\
\text { dence }\end{array}$ \\
\end{tabular} & \begin{tabular}{|l|}
$\begin{array}{l}\text { Indepen- } \\
\text { dence }\end{array}$ \\
\end{tabular} & $\begin{array}{l}\text { Depen- } \\
\text { dence }\end{array}$ \\
\hline & $n(\%)$ & $n(\%)$ & $n(\%)$ & $n(\%)$ & $n(\%)$ & $n(\%)$ & $n(\%)$ & $n(\%)$ \\
\hline All groups & $483(83.6)$ & $95(16.4)$ & $440(76.1)$ & $138(23.9)$ & $513(88.8)$ & 65 (11.2) & $454(78.5)$ & $124(21.5)$ \\
\hline Physical disability & $119(66.9)$ & $59(33.1)$ & $111(62.4)$ & 67 (37.6) & $143(80.3)$ & 35 (19.7) & $123(69.1)$ & $55(30.9)$ \\
\hline \multirow[t]{4}{*}{$\begin{array}{l}\text { Physical disability type } \\
\text { hearing impairment } \\
\text { vision impairment } \\
\text { speech impairment } \\
\text { orthopedic disorders }\end{array}$} & $\begin{array}{l}14(31.8) \\
70(80.5) \\
6(75.0) \\
49(70.0) \\
\end{array}$ & \begin{tabular}{|l|}
$30(68.2)$ \\
$17(19.5)$ \\
$2(25.0)$ \\
$21(30.0)$
\end{tabular} & $\begin{array}{l}36(81.8) \\
71(81.6) \\
8(100.0) \\
20(28.6) \\
\end{array}$ & $\begin{array}{l}8(18.2) \\
16(18.4) \\
0(0.0) \\
50(71.4)\end{array}$ & $\begin{array}{l}38(86.4) \\
76(87.4) \\
8(100.0) \\
41(58.6) \\
\end{array}$ & \begin{tabular}{|l}
$6(13.6)$ \\
$11(12.6)$ \\
$0(0.0)$ \\
$29(41.4)$
\end{tabular} & $\begin{array}{l}38(86.4) \\
73(83.9) \\
8(100.0) \\
24(34.3) \\
\end{array}$ & \begin{tabular}{|l}
$6(13.6)$ \\
$14(16.1)$ \\
$0(0.0)$ \\
$46(65.7)$ \\
\end{tabular} \\
\hline & \multicolumn{2}{|l|}{ Laundering } & \multicolumn{2}{|l|}{ Travelling } & \multicolumn{2}{|c|}{ Managing money } & \multicolumn{2}{|c|}{ Managing medications } \\
\hline & $\begin{array}{l}\text { Indepen- } \\
\text { dence }\end{array}$ & $\begin{array}{l}\text { Depen- } \\
\text { dence }\end{array}$ & $\begin{array}{l}\begin{array}{l}\text { Indepen- } \\
\text { dence }\end{array} \\
\end{array}$ & \begin{tabular}{|l}
$\begin{array}{l}\text { Depen- } \\
\text { dence }\end{array}$ \\
\end{tabular} & $\begin{array}{l}\text { Indepen- } \\
\text { dence }\end{array}$ & \begin{tabular}{|l}
$\begin{array}{l}\text { Depen- } \\
\text { dence }\end{array}$ \\
\end{tabular} & $\begin{array}{l}\text { Indepen- } \\
\text { dence }\end{array}$ & $\begin{array}{l}\begin{array}{l}\text { Depen- } \\
\text { dence }\end{array} \\
\end{array}$ \\
\hline & $n(\%)$ & $n(\%)$ & $n(\%)$ & $n(\%)$ & $n(\%)$ & $n(\%)$ & $n(\%)$ & $n(\%)$ \\
\hline All groups & $486(84.1)$ & $92(15.9)$ & 411 (71.1) & $167(28.9)$ & $516(89.3)$ & 62 (10.7) & $561(97.1)$ & $17(2.9)$ \\
\hline Physical disability & $134(75.3)$ & $44(24.7)$ & $121(68.0)$ & $57(32.0)$ & $150(84.3)$ & 28 (15.7) & $167(93.8)$ & $11(6.2)$ \\
\hline $\begin{array}{l}\text { Physical disability type } \\
\text { hearing impairment } \\
\text { vision impairment } \\
\text { speech impairment } \\
\text { orthopedic disorders }\end{array}$ & $\begin{array}{l}38(86.4) \\
68(78.2) \\
8(100.0) \\
40(57.1)\end{array}$ & $\begin{array}{l}6(13.6) \\
19(21.8) \\
0(0.0) \\
30(42.9)\end{array}$ & $\begin{array}{l}36(81.8) \\
73(83.9) \\
8(100.0) \\
24(34.3)\end{array}$ & $\begin{array}{l}8(18.2) \\
14(16.1) \\
0(0.0) \\
46(65.7)\end{array}$ & $\begin{array}{l}38(86.4) \\
76(87.4) \\
8(100.0) \\
52(74.3)\end{array}$ & $\begin{array}{l}6(13.6) \\
11(12.6) \\
0(0.0) \\
18(25.7)\end{array}$ & $\begin{array}{l}38(86.4) \\
84(96.6) \\
8(100.0) \\
61(87.1)\end{array}$ & $\begin{array}{l}6(13.6) \\
3(3.4) \\
0(0.0) \\
9(12.9)\end{array}$ \\
\hline
\end{tabular}




\begin{tabular}{|c|c|c|c|}
\hline & $\begin{array}{l}\text { Indepen- } \\
\text { dence }\end{array}$ & $\begin{array}{l}\text { Depen- } \\
\text { dence }\end{array}$ & $p$ \\
\hline Variables & $n(\%)$ & $n(\%)$ & \\
\hline $\begin{array}{l}\text { Gender } \\
\text { female } \\
\text { male } \\
\end{array}$ & $\begin{array}{l}219(70.9) \\
169(62.8)\end{array}$ & $\begin{array}{l}90(29.1) \\
100(37.2)\end{array}$ & 0.040 \\
\hline $\begin{array}{l}\text { Age } \\
\begin{array}{l}65-74 \\
75+\end{array}\end{array}$ & $\begin{array}{l}231(71.5) \\
157(61.6) \\
\end{array}$ & $\begin{array}{l}92(28.5) \\
98(38.4) \\
\end{array}$ & 0.011 \\
\hline $\begin{array}{l}\text { Education level } \\
\text { primary school or higher } \\
\text { literate and illiterate }\end{array}$ & $\begin{array}{l}236(60.8) \\
152(39.2)\end{array}$ & $\begin{array}{l}114(60.0) \\
76(40.0)\end{array}$ & 0.849 \\
\hline $\begin{array}{l}\text { Number of people the partici- } \\
\text { pants live together with } \\
\text { at least one person } \\
\text { alone }\end{array}$ & $\begin{array}{l}331 \text { (86.9) } \\
50(13.1)\end{array}$ & $\begin{array}{l}134(74.9) \\
45(25.1)\end{array}$ & $<0.001$ \\
\hline $\begin{array}{l}\text { Perceived income level } \\
\text { adequate } \\
\text { inadequate }\end{array}$ & $\begin{array}{l}317(67.7) \\
71(64.5)\end{array}$ & $\begin{array}{l}151(32.3) \\
39(35.5)\end{array}$ & 0.522 \\
\hline $\begin{array}{l}\text { Perceived health level } \\
\text { good and moderate } \\
\text { poor }\end{array}$ & $\begin{array}{l}340(87.6) \\
48(12.4)\end{array}$ & $\begin{array}{l}70(36.8) \\
120(63.2)\end{array}$ & $<0.001$ \\
\hline $\begin{array}{l}\text { Chronic disease } \\
\text { no } \\
\text { yes } \\
\end{array}$ & $\begin{array}{l}76(84.4) \\
312(63.9)\end{array}$ & $\begin{array}{l}14(15.6) \\
176(36.1)\end{array}$ & $<0.001$ \\
\hline $\begin{array}{l}\text { Physical disability } \\
\text { no } \\
\text { yes }\end{array}$ & $\begin{array}{l}292(73.0) \\
96(53.9)\end{array}$ & $\begin{array}{l}108(27.0) \\
82(46.1)\end{array}$ & $<0.001$ \\
\hline $\begin{array}{l}\text { Physical disability type } \\
\text { - hearing impairment } \\
\text { no } \\
\text { yes } \\
\text { - vision impairment } \\
\text { no } \\
\text { yes } \\
\text { - speech impairment } \\
\text { no } \\
\text { yes } \\
\text { - orthopedic disorders } \\
\text { no } \\
\text { yes }\end{array}$ & $\begin{array}{l}366(68.5) \\
22(50.0) \\
316(64.4) \\
72(82.8) \\
382(67.0) \\
6(75.0) \\
372(73.2) \\
16(22.9)\end{array}$ & $\begin{array}{l}168(31.5) \\
22(50.0) \\
175(35.6) \\
15(17.2) \\
188(33.0) \\
2(25.0) \\
136(26.8) \\
54(77.1)\end{array}$ & $\begin{array}{l}0.633 \\
<0.001\end{array}$ \\
\hline
\end{tabular}

In Table 4, the relationship between physical disability types and IADL scores of the elderly determined using a multivariate binary logistic regression analysis is presented (Enter strategy). In a model adjusted for gender, age, number of people the elderly lived with, perceived health level and chronic diseases, the IADL variance was explained at a rate of $43.8 \%$ according to Nagelkerke $R^{2}(p<0.001)$. The probability of experiencing IADL limitations was 5.32 times higher in those with hearing impairments than in those without hearing impairments (AOR, $95 \% \mathrm{Cl}$ : $2.41-11.72, p<0.001$ ) and 3.65 times higher in those with orthopedic disorders than in those without orthopedic disorders (AOR, 95\% Cl: 1.80-7.38, $p<0.001$ ). The likelihood of having an IADL dependency was lower in participants with visual impairments than it was in those without a visual impairment $(A O R=$ $0.21,95 \% \mathrm{Cl}: 0.09-0.49, p<0.001$ ) (Table 4).

\section{Discussion}

The present study set out to determine the IADL dependency levels of adults aged 65 years and older living in Kirklareli, Turkey, and also to investigate the relationship between IADL score and physical disability. To our knowledge, this study is the first to investigate the relationship between IADL and physical disabilities, such as hearing impairments, visual impairments, speech impairments and orthopedic disorders, in elderly people living in Kirklareli.

In the present study, approximately one-third of all participants and half of the participants with physical disabilities were dependent on others to perform at least one ADL. While the rate of $A D L$ dependency in the participants of our study was lower than the rate reported in recent studies conducted in elderly Sri Lankan adults who were 60 years of age and older (84.4\%) [5] and in Turkish adults 60 years of age and older with comorbidities living in Istanbul (64\%) [8], this was roughly consistent with that determined in current studies conducted in a United States (US) sample with vision loss (ranging from: $25.0 \%$ to $44.7 \%$ ) [4], in elderly Japanese people with hearing loss (44.8\%) [14] and in Chinese adults aged 80 and over (37.9\%) [7]. However, the rate found in the present study was higher than those reported in recent studies conducted in Irish adults 65 years of age and older (11\%) [6] and in Netherlanders 75 years of age and older (12.5\%) [25]. The incidence rate obtained in our study may be compatible with those of other studies that reported a high frequency. As people with full dependence, such as bedridden elderly, are less likely to present to FHCs, the frequency rate obtained in the present study might be lower than the actual prevalence. In addition,

\begin{tabular}{|c|c|c|c|c|}
\hline $\begin{array}{l}\text { Physical disability } \\
\text { type }\end{array}$ & $\begin{array}{l}\text { Unadjusted model } \\
\text { OR ( } 95 \% \mathrm{Cl} \text { of OR) }\end{array}$ & $p$ & $\begin{array}{l}\text { *Adjusted model } \\
\text { AOR ( } 95 \% \mathrm{Cl} \text { of AOR) }\end{array}$ & $p$ \\
\hline $\begin{array}{l}\text { Hearing impairment } \\
\text { no } \\
\text { yes }\end{array}$ & $\begin{array}{l}1 \\
2.17(1.17 \text { to } 4.04)\end{array}$ & 0.014 & $\begin{array}{l}1 \\
5.32(2.41 \text { to } 11.72)\end{array}$ & $<0.001$ \\
\hline $\begin{array}{l}\text { Vision impairment } \\
\text { no } \\
\text { yes }\end{array}$ & $\begin{array}{l}1 \\
0.37 \text { (0.20 to } 0.67)\end{array}$ & 0.001 & $\begin{array}{l}1 \\
0.21 \text { (0.09 to } 0.49)\end{array}$ & $<0.001$ \\
\hline $\begin{array}{l}\text { Speech impairment } \\
\text { no } \\
\text { yes }\end{array}$ & $\begin{array}{l}1 \\
0.67(0.13 \text { to } 3.38)\end{array}$ & 0.635 & $\begin{array}{l}1 \\
1.60(0.20 \text { to } 12.81)\end{array}$ & 0.657 \\
\hline $\begin{array}{l}\text { Orthopedic disorders } \\
\text { no } \\
\text { yes }\end{array}$ & $\begin{array}{l}1 \\
9.23 \text { (5.11 to } 16.67)\end{array}$ & $<0.001$ & $\begin{array}{l}1 \\
3.651(1.80 \text { to } 7.38)\end{array}$ & $<0.001$ \\
\hline
\end{tabular}

Reference category: No. AOR: Adjusted Odds Ratio; Cl: Confidence Interval. Method: Enter strategy. Omnibus Tests of Model Coefficients: $p<0.001$; Nagelkerke $R$ Square $=0.43$; Hosmer and Lemeshow Test $=0.88$.

*Adjusted model for age, gender, education level, number of people the participants live together with, perceived income level, perceived health level and chronic disease. 
differences between the results of the present study and those of other studies may have stemmed from differences between the characteristics of the respective sample groups, such as age, disability type, chronic disease rates and regional differences. In addition, the low frequency rates in Irish people and in Netherlanders may have been associated with the quality of health services and social support systems available in those countries.

In our study, while approximately one-quarter of the elderly people experienced limitations in ADLs, such as traveling, shopping and household tasks, one-third of the physically disabled elderly participants reported limitations in shopping, using the phone and traveling. Community-based studies conducted in adults 65 years of age and older in the US, in the United Kingdom and in 12 other countries in Europe reported that of all $A D L s$, the ones in which the participants experienced the greatest limitations were shopping (12.3\%), preparing meals $(8.2 \%)$ and handling money (7.9\%); the risk of dependence for all ADLs was significantly high [26]. In contrast, adults in Sri Lanka who were 60 years of age and older reported difficulties in shopping $(67.9 \%)$, preparing meals $(61.7 \%)$, managing medications (46.6\%) and managing money (35.7\%) [5]. In the elderly population, the presence of a chronic disease accompanied by poor quality of life makes any disability even more disadvantageous $[25,27,28]$. In a randomized, controlled study conducted in the Netherlands in the elderly, nearly half of whom had at least one disability, the participants reported the greatest limitations in performing household tasks (44.8\%), traveling (26.9\%) and shopping (23\%); as age increased, so did the risk of being disabled [2]. In a meta-analytical study involving 19,246 cancer patients, $36.7 \%$ of the participants were dependent on others for performing basic ADLs, and $54.6 \%$ were more dependent on others for doing household tasks, traveling and shopping [29]. One explanation for the differences in our findings and those from other studies regarding ADL may have been due to the memory factor, as our respondents were required to report any difficulties based upon their own memory recall.

The present study found that participants with hearing impairments required assistance while using the phone (68.2\%) and that the risk of ADL dependency was 5.3 times higher in people with hearing impairments after adjusting for potential confounding variables. In a study conducted in Japan that followed elderly people over 65 years of age with hearing loss for three years, there was a decrease in the IADL scores of $44.8 \%$ of the participants, and the risk of ADL limitations was 1.79 times higher in those with hearing loss than for those without hearing loss [14]. In a study conducted in Nordic hospitals, the risk of experiencing limitations in three or more ADL tasks was 1.9 times higher in elderly people who were at least 75 years of age with a hearing impairment; this risk increased by 2.7 times in those with both hearing and vision impairments [30]. In a study conducted in Scandinavian hospitals, patients aged 75 years and older with hearing loss were determined to need the most assistance while using the phone, doing household tasks and shopping [31]. In the Netherlands, in a study conducted with elderly people at least 65 years of age who had a dual sensory impairment (vision and hearing), the ADL limitations increased significantly, and the risk increased with age [18]. It was also determined that older people with a dual sensory impairment had the greatest limitations while doing household tasks, traveling, shopping and preparing meals $[28,32,33]$. The differences between our finding and the findings of other studies in literature may have been caused not only by hearing loss but also by the participants' inadequacy in using technologic devices, such as smartphones.

This study found that those with visual impairments received the most assistance in activities such as laundering $(21.8 \%)$ and using the phone (19.5\%), while people without visual impairments performed ADLs more independently (82.8\%). In the US, it was determined that individuals 60 years of age or older with age-related macular degeneration (AMD) and glaucoma frequently received assistance, particularly while pre- paring meals, shopping and traveling, and that the risk of IADL dependency was approximately 3.5 times higher in people with AMD [4]. In other studies, it was reported that ADL dependency was high in patients with visual impairments or visual acuity loss $[4,13]$, and visual acuity loss negatively affected ADL levels and increased the risk of mortality [34]. Our findings were different from those in literature, which can be explained by the fact that the data obtained was self-reported, and the participants in our sample were more likely to require wearing glasses.

In the present study, elderly participants with a speech impairment experienced limitations only in using the phone (25\%); in a model that was corrected according to some characteristics, no relationship at all was found. People with early stage dementia with decreased verbal fluency also experienced more limitations in performing ADLs [24]. Motor deficits due to dementia in Parkinson's disease were found to cause ADL impairments [16]. In a study conducted in Brazil on patients with spinocerebellar ataxia type 10, including dysarthria and reduced cognitive ability, a longer duration of disease was associated with a greater ADL dependency [35]. In other studies conducted on the issue, a correlation was found between functional ability and cognition, which affected the performance of $\operatorname{ADLs}[6,24,30]$. Our result was different from that in literature, which may have been influenced by the fact that people with mental and cognitive disorders were not included in our study, as well as that the number of people with speech disorders in our sample was low. If future studies are conducted with larger samples that include people with speech disorders, more accurate results may be obtained.

In the current study, approximately three-fourths (77.1\%) of elderly people with orthopedic disorders experienced limitations in at least one ADL, and the risk of ADL dependency was 3.6 times higher in participants with orthopedic disorders after adjustments for potential confounding variables were made. Participants with orthopedic disorders were most dependent on others while shopping (71.4\%), doing household tasks (65.7\%) and traveling (65.7\%). According to literature, patients with hip fractures demonstrated low IADL scores, and their recovery to pre-operative IADL levels was not complete even after six months to one year. The mortality risk was also high in elderly patients with hip fractures whose IADL scores were low [36]. In a case-control study conducted with patients with osteoporotic fractures (evidence level III), a one-unit increase in the IADL score decreased the likelihood of fracture by approximately $30 \%$ [15]. Due to decreases in muscle strength and muscle mass in people of advanced ages, ADL limitations are more common among the elderly [18]. In people with sarcopenia, only gait speed was predictive of IADL disability [25]. According to a study conducted in the US, rheumatism causes disability in adults aged 65 and over, and approximately $30 \%$ of adults have difficulty performing ADL due to rheumatism [12]. Our results were consistent with those of previous studies in literature and illustrate the disadvantages faced by people who have an orthopedic disorder.

\section{Limitations of the study}

Due to its cross-sectional design, the lack of sequentiality in causality was the main limitation of this study. The other limitations of the study were that the data relied on the self-report of the participants and that people with mental and cognitive disorders were not included in the study sample. Because the study data was collected from elderly participants who presented to FHCs, the results of the study also cannot be generalized to all elderly people.

\section{Conclusions}

Both the frequency of physical disability and dependency of performance of ADLs were high in the elderly. Travelling and shopping were two of the IADLs that all the participants with 
and without a physical disability were dependent on others to perform. Elderly individuals with hearing impairments and those with orthopedic disorders were more likely to be dependent on other people while performing at least one ADL.

Further efforts are needed to protect the autonomy of the elderly while they perform ADLs, to prevent further disability and to develop interventions for frail groups. To ensure the bio-psycho-social rehabilitation of elderly people with physical disabilities, policymakers should design health systems for the elderly and activate any available social support systems. Raising the awareness of physicians and other health professionals who work in primary healthcare institutions about these problems in the elderly and also in elderly people with disabilities may encourage these professionals to take preventive measures and cooperate with relevant institutions to reduce the impact of such problems. The results of this study will guide the planning of these services and determination of priority to be provided for the elderly with disabilities in FHCs.

Source of funding: This work was funded from the authors' own resources.

Conflicts of interest: The authors declare no conflicts of interest.

\section{References}

1. World Health Organization. World report on ageing and health. Geneva: WHO; 2015.

2. Bleijenberg N, Zuithoff NPA, Smith AK, et al. Disability in the individual ADL, IADL, and mobility among older adults: a prospective cohort study. J Nutr Health Aging 2017; 21(8): 897-903.

3. Kojima G. Frailty as a predictor of disabilities among community-dwelling older people: a systematic review and meta-analysis. Disabil Rehabil 2017; 39(19): 1897-1908.

4. Hochberg C, Maul E, Chan ES, et al. Association of vision loss in glaucoma and age-related macular degeneration with IADL disability. Invest Ophthalmol Vis Sci 2012; 53(6): 3201-3206.

5. Siriwardhana DD, Weerasinghe MC, Rait G, et al. Association between frailty and disability among rural community-dwelling older adults in Sri Lanka: a cross-sectional study. BMJ Open 2020; 10(3): e034189.

6. Connolly D, Garvey J, McKee G. Factors associated with ADL/IADL disability in community dwelling older adults in the Irish longitudinal study on ageing (TILDA). Disabil Rehabil 2017; 39(8): 809-816.

7. Su P, Ding H, Zhang W, et al. The association of multimorbidity and disability in a community-based sample of elderly aged 80 or older in Shanghai, China. BMC Geriatr 2016; 16(1): 178.

8. Bahat $\mathrm{G}$, Tufan $\mathrm{F}$, Bahat $\mathrm{Z}$, et al. Comorbidities, polypharmacy, functionality and nutritional status in Turkish community-dwelling female elderly. Aging Clin Exp Res 2014; 26(3): 255-259.

9. Scheel-Hincke LL, Möller S, Lindahl-Jacobsen R, et al. Cross-national comparison of sex differences in ADL and IADL in Europe: findings from SHARE. Eur J Ageing 2019; 17(1): 69-79.

10. Serrano-Alarcón M, Perelman J. Ageing under unequal circumstances: a cross-sectional analysis of the gender and socioeconomic patterning of functional limitations among the Southern European elderly. Int J Equity Health 2017; 16(1): 175.

11. Qian J, Ren X. Association between comorbid conditions and BADL/IADL disability in hypertension patients over age 45: based on the China health and retirement longitudinal study (CHARLS). Medicine (Baltimore) 2016; 95(31): e4536.

12. Lafortune G, Balestat G, eds. Trends in severe disability among elderly people: assessing the evidence in 12 OECD countries and the future implications. Paris: AndrÈ-Pascal; 2007.

13. Naël V, Pérès K, Carrière I, et al. Visual impairment, under corrected refractive errors, and activity limitations in older adults: findings from the three-city alienor study. Invest Ophthalmol Vis Sci 2017; 58(4): 2359-2365.

14. Yamada M, Nishiwaki Y, Michikawa T, et al. Self-reported hearing loss in older adults is associated with future decline in instrumental activities of daily living but not in social participation. J Am Geriatr Soc 2012; 60(7): 1304-1309.

15. Shu MM, Canhos AL, Ocampos GP, et al. Profile of patients with osteoporotic fractures at a tertiary orthopedic trauma center. Acta Ortop Bras 2018; 26(2): 117-122.

16. Rasovska H, Rektorova I. Instrumental activities of daily living in Parkinson's disease dementia as compared with Alzheimer's disease: relationship to motor disability and cognitive deficits: a pilot study. J Neurol Sci 2011; 310(1-2): 279-282.

17. Blomgren $C$, Jood K, Jern C, et al. Long-term performance of instrumental activities of daily living (IADL) in young and middle-aged stroke survivors: results from SAHLSIS outcome. Scand J Occup Ther 2018; 25(2): 119-126.

18. Mueller-Schotte S, Zuithoff NPA, van der Schouw YT, et al. Trajectories of limitations in instrumental activities of daily living in frail older adults with vision, hearing, or dual sensory loss. J Gerontol A Biol Sci Med Sci 2019; 74(6): 936-942.

19. GBD 2017 DALYs and HALE Collaborators. Global, regional, and national disability-adjusted life-years (DALYs) for 359 diseases and injuries and healthy life expectancy (HALE) for 195 countries and territories, 1990-2017: a systematic analysis for the Global Burden of Disease Study 2017. Lancet 2018; 392(10159): 1859-1922.

20. About chronic diseases [cited 2.04.2020]. Available from URL: https://www.cdc.gov/chronicdisease/about/index.htm.

21. Onal Yardimci E. The correlation of the health problems of the elderly teachers who live in Istanbul with their daily life activities and instrumental activities of daily life [dissertation]. Istanbul: University of Istanbul; 1995.

22. Guzel A, Uner S, Turan S, et al. Turkish validity and reliability of Lawton and Brody instrumental daily life activities scale. In: Karakoc FY, Abacıgil F, Onde M, et al., eds. 3rd International 21st National Public Health Congress; 2019 Nov 26-30; Antalya, Turkey; $2019: 200$.

23. Address Based Population Registration System, Turkey Statistical Institute [cited 20.09.2019]. Available from URL: https://biruni.tuik. gov.tr/medas/?locale=tr.

24. Martyr A, Clare L, Nelis SM, et al. Verbal fluency and awareness of functional deficits in early-stage dementia. Clin Neuropsychol 2012; 26(3): 501-519.

25. Gobbens RJ, Assen MA van. The Prediction of ADL and IADL disability using six physical indicators of frailty: a longitudinal study in the Netherlands. Curr Gerontol Geriatr Res 2014; 2014: 358137.

26. Chan KS, Kasper JD, Brandt J, et al. Measurement equivalence in ADL and IADL difficulty across international surveys of aging: findings from the HRS, SHARE, and ELSA. J Gerontol B Psychol Sci Soc Sci 2012; 67(1): 121-132.

27. Sousa RM, Ferri $C P, A c o s t a ~ D$, et al. Contribution of chronic diseases to disability in elderly people in countries with low and middle incomes: a 10/66 Dementia Research Group population-based survey. Lancet 2009; 374(9704): 1821-1830.

28. Liu PL, Cohen HJ, Fillenbaum GG, et al. Association of co-existing impairments in cognition and self-rated vision and hearing with health outcomes in older adults. Gerontol Geriatr Med 2016; 2: 1-9.

29. Neo J, Fettes L, Gao W, et al. Disability in activities of daily living among adults with cancer: a systematic review and meta-analysis. Cancer Treat Rev 2017; 61: 94-106. 
30. Mlinac ME, Feng MC. Assessment of activities of daily living, self-care, and independence. Arch Clin Neuropsychol 2016; 31(6): 506-516.

31. Grue EV, Ranhoff AH, Noro A, et al. Vision and hearing impairments and their associations with falling and loss of instrumental activities in daily living in acute hospitalized older persons in five Nordic hospitals. Scand J Caring Sci 2009; 23(4): 635-643.

32. Soto-Perez-de-Celis E, Sun CL, Tew WP, et al. Association between patient-reported hearing and visual impairments and functional, psychological, and cognitive status among older adults with cancer. Cancer 2018; 124(15): 3249-3256.

33. Guthrie DM, Davidson JGS, Williams N, et al. Combined impairments in vision, hearing and cognition are associated with greater levels of functional and communication difficulties than cognitive impairment alone: analysis of interRAl data for home care and long-term care recipients in Ontario. PLoS One 2018; 13(2): e0192971.

34. Christ SL, Zheng DD, Swenor BK, et al. Longitudinal relationships among visual acuity, daily functional status, and mortality: the Salisbury Eye Evaluation Study. JAMA Ophthalmol 2014; 132(12): 1400-1406.

35. Santos LR, Teive HAG, Lopes Neto FDN, et al. Quality of life in individuals with spinocerebellar ataxia type 10: a preliminary study. Arq Neuropsiquiatr 2018; 76(8): 527-533.

36. Pioli G, Lauretani F, Davoli ML, et al. Older people with hip fracture and IADL disability require earlier surgery. J Gerontol A Biol Sci Med Sci 2012; 67(11): 1272-1277.

Tables: 4

Figures: 0

References: 36

Received: 15.03.2020

Reviewed: 19.03.2020

Accepted: 4.05.2020

Address for correspondence:

Yeliz Mercan, MPH, PhD

Kirklareli University School of Health

39000 Kırklareli

Turkey

Tel.: +90 507 239-29-95

E-mail: mercan.yeliz@gmail.com 